\title{
Interaction of Mycobacterium tuberculosis enoyl-ACP Reductase with INH-NADP: New Insight into the Mechanism of Action of and Resistance to Isoniazid
}

\author{
Argyrides Argyrou ${ }^{\dagger}$, Matthew W. Vetting, and John S. Blanchard* \\ Department of Biochemistry, Albert Einstein College of Medicine, 1300 Morris Park Avenue, Bronx, NY 10461 \\ ${ }^{\dagger}$ Present address: Department of Chemical Enzymology, Bristol-Myers Squibb Pharmaceutical Co., Research \& \\ Development, PO Box 5400, Princeton, NJ 08543-5400
}

\section{Supporting Information}

Cloning of inhA into plasmid pET15b(+). The inhA gene (Rv1484) encoding enoyl-ACP reductase from $M$. tuberculosis was amplified by PCR to generate blunt-ended DNA with Ndel and BamHI restriction sites at the ends. The oligonucleotide primers were: 5'-CGCCATATGACAGGACTGCTGGACGGCAAACGG-3' and 5'CGCGGATCCCTAGAGCAATTGGGTGTGCGC-3'. The amplified DNA product was ligated into the pCR ${ }^{\circledR}$-Blunt plasmid and transformed into One Shot ${ }^{\mathrm{TM}}$ TOP10 cells following the instructions supplied by the manufacturer (Invitrogen). Plasmid DNA isolated from these cells was then digested with $\mathrm{Ndel}$ and $\mathrm{BamHI}$ and the purified insert was ligated into plasmid $\mathrm{pET}-15 \mathrm{~b}(+)$ (Novagen) previously linearized with the same restriction enzymes. Cloning into these restriction sites adds a thrombin-cleavable hexahistidine tag at the N-terminus of InhA.

\section{Expression and Purification of InhA.}

Expression. Competent Escherichia coli BL21 (DE3) Star ${ }^{\mathrm{TM}}$ cells (Invitrogen) were transformed with the recombinant plasmid pET15b(+):inhA and grown at $37^{\circ} \mathrm{C}$ to an $A_{600 \mathrm{~nm}}$ of 0.7 in Luria-Bertani medium containing $50 \mu \mathrm{g} \mathrm{mL}$ ampicillin. The cells were cooled to $18{ }^{\circ} \mathrm{C}$ and induction of protein expression by the addition of $0.5 \mathrm{mM} \mathrm{IPTG}$ was allowed to proceed for $20 \mathrm{~h}$ at $18^{\circ} \mathrm{C}$.

Purification. All operations were carried out at $4{ }^{\circ} \mathrm{C}$. Cell paste $(25 \mathrm{~g})$ was suspended in $40 \mathrm{~mL}$ of buffer $[50 \mathrm{mM}$ tris, $25 \mathrm{mM}$ imidazole, $10 \mathrm{mM} \mathrm{MgCl}_{2}, \mathrm{pH}$ 7.5] containing three tablets of Complete ${ }^{\mathrm{TM}}$ protease inhibitor cocktail (Boehringer Mannheim), $20 \mathrm{mg}$ chicken egg white lysozyme (Sigma), and $10 \mathrm{mg}$ bovine pancreas DNasel (Boehringer Mannheim). The cells were disrupted in a French pressure cell and cell debris was removed by centrifugation at $20000 \mathrm{~g}$ for $60 \mathrm{~min}$. The supernatant was applied to a $40 \mathrm{~mL}$ column of Ni-NTA His·Bind Superflow (Novagen) equilibrated with Buffer A (20 mM TEA, $30 \mathrm{mM}$ imidazole, $300 \mathrm{mM} \mathrm{KCl}, \mathrm{pH}$ 7.8). The column was washed with 150 $\mathrm{mL}$ of the same buffer and then eluted with a linear gradient $(800 \mathrm{~mL})$ from $0 \%$ to $100 \%$ Buffer B $(20 \mathrm{mM} \mathrm{TEA}, 500$ $\mathrm{mM}$ imidazole, $300 \mathrm{mM} \mathrm{KCl}, \mathrm{pH}$ 7.8). Fractions containing pure InhA were pooled, centrifuged as above, and dialyzed for $4 \mathrm{~h}$ against $4 \mathrm{~L}$ of $20 \mathrm{mM}$ bis-tris propane buffer, $\mathrm{pH} 7.8$, containing $2 \mathrm{mM} \mathrm{CaCl}_{2}$. The protein was concentrated 
down to $10 \mathrm{~mL}$ and cleaved for $20 \mathrm{~h}$ at $4{ }^{\circ} \mathrm{C}$ using 1000 units of thrombin (Amersham Biosciences). The cleaved protein was dialyzed against $4 \mathrm{~L}$ of buffer $(20 \mathrm{mM}$ Hepes, $1 \mathrm{mM}$ EDTA, $1 \mathrm{mM}$ DTT, pH 7.5) for $14 \mathrm{~h}$, and concentrated down to $9.4 \mathrm{mg} \mathrm{mL}^{-1}(350 \mu \mathrm{M})$. A portion was used for crystallographic studies while the remainder was stored at -20 ${ }^{\circ} \mathrm{C}$ in $50 \%$ glycerol. A total of $80 \mathrm{mg}$ of homogeneous InhA was obtained from $25 \mathrm{~g}$ of cell paste.

Determination of Protein Concentration. The concentration of InhA was determined from $\varepsilon_{280 \mathrm{~nm}}=30440 \mathrm{M}^{-1} \mathrm{~cm}^{-1}$. Assay for InhA. All kinetic assays were performed under initial rate conditions. The NADH-dependent reduction of 2-trans-octenoyl-CoA catalyzed by InhA was assayed spectrophotometrically at $340 \mathrm{~nm}$ associated with the oxidation of $\operatorname{NADH}\left(\varepsilon_{340 \mathrm{~nm}}=6220 \mathrm{M}^{-1} \mathrm{~cm}^{-1}\right)$.

Synthesis and Purification of 2-trans-octenoyl-CoA. 2-Trans-octenoyl-CoA was synthesized and purified using methods described previously. ${ }^{1,2}$

Synthesis and Purification of INH-NADP. The mixture of INH-NADP adducts were synthesized and purified as described previously. ${ }^{3}$ The $A_{260 \mathrm{~nm}}$ to $A_{324 \mathrm{~nm}}$ ratio (an indicator of purity) of the purified product was 4.0 , which is close to the value of 3.94 reported previously for INH-NAD. ${ }^{3}$ The concentration of INH-NADP was determined from $\varepsilon_{324 \mathrm{~nm}}=$ $6900 \mathrm{M}^{-1} \mathrm{~cm}^{-1}$.

Crystallization of the InhA:INH-NADP Complex and Data Collection. Prior to crystallization, InhA at $9.4 \mathrm{mg} \mathrm{mL}^{-1}$ $(350 \mu \mathrm{M})$ was incubated with the INH-NADP adduct $(4.8 \mathrm{mM})$ for $1 \mathrm{~h}$ at $4{ }^{\circ} \mathrm{C}$. The InhA:INH-NADP complex was crystallized by vapour diffusion under oil at $18^{\circ} \mathrm{C}$. Equal volumes $(2 \mu \mathrm{L}$ each) of the protein:inhibitor complex and precipitant were combined under $150 \mu \mathrm{L}$ of FISHER silicon oil and incubated open to the room humidity. Crystals with a hexagonal bipyramidal morphology grew from conditions containing 20-25\% of 2-methyl-2,4-pentanediol (MPD), $100 \mathrm{mM}$ Bicine $\mathrm{pH}$ 9.0. Prior to vitrification in liquid nitrogen, the crystal was incubated for $10 \mathrm{~s}$ in $35 \% \mathrm{MPD}, 100 \mathrm{mM}$ Bicine pH 9.0. Data were collected from a single crystal on an MSC R-AXIS IV++ image plate detector using CuK $\alpha$ radiation generated from a Rigaku RU-H3R X-ray generator and processed using MOSFLM. ${ }^{4}$

Structure Determination and Refinement. The structure of the InhA:INH-NADP complex was phased using the molecular replacement package AMORE and the InhA:NAD complex (PDBID: 1ENY) as the search model. The structure was fit to the data using iterative model building within the molecular graphics program $\mathrm{COOT}^{5}$ and refinement within REFMAC. ${ }^{6}$ Refinement parameters for the INH-NADP ligand were generated by the program PRODRG. ${ }^{7}$ Data collection and refinement statistics are shown in Table 1. 


\begin{tabular}{|c|c|}
\hline \multicolumn{2}{|l|}{ Data Collection } \\
\hline Space group & $\mathrm{P} 6{ }_{2} 22$ \\
\hline Cell dimensions $(\AA)$ & $a=99.128 \quad c=139.274$ \\
\hline Resolution ( $\AA$ ) & $40-2.5(2.64-2.5)$ \\
\hline Completeness (\%) & $99.8(100)$ \\
\hline Redundancy & $11.6(11.7)$ \\
\hline $1 / \sigma(I)$ & $36.7(7.5)$ \\
\hline $\mathrm{R}_{\text {sym }}(\%)$ & $0.053(0.337)$ \\
\hline \multicolumn{2}{|l|}{ Refinement } \\
\hline Resolution $(\AA)$ & $40-2.5(2.57-2.5)$ \\
\hline $\mathrm{R}_{\text {factor }}(\%) / \mathrm{R}_{\text {free }}(\%)^{2}$ & $18.5 / 21.7(24.6 / 27.3)$ \\
\hline \multicolumn{2}{|l|}{ \# Atoms } \\
\hline protein & 1989 \\
\hline solvent / inhibitor & $42 / 56$ \\
\hline \multicolumn{2}{|l|}{ Average B-factors $\left(\AA^{2}\right)$} \\
\hline protein & 37.8 \\
\hline solvent / inhibitor & $36.3 / 42.3$ \\
\hline \multicolumn{2}{|l|}{ RMS deviations } \\
\hline bonds $(\AA)$ & 0.012 \\
\hline angles $\left(^{\circ}\right)$ & 1.69 \\
\hline \multicolumn{2}{|c|}{$\begin{array}{l}{ }^{1} \text { Statistics in parentheses are for the highest resolution shell } \\
{ }^{2} \mathrm{R}_{\text {free }} \text { calculated from a set of reflections ( } 5 \% \text { of data) omitted from refinement }\end{array}$} \\
\hline
\end{tabular}




\section{REFERENCES}

(1) Quemard, A.; Sacchettini, J. C.; Dessen, A.; Vilcheze, C.; Bittman, R.; Jacobs, W. R., Jr.; Blanchard, J. S. Biochemistry 1995, 34, 8235-8241.

(2) Parikh, S.; Moynihan, D. P.; Xiao, G.; Tonge, P. J. Biochemistry 1999, 38, 13623-13634.

(3) Ducasse-Cabanot, S.; Cohen-Gonsaud, M.; Marrakchi, H.; Nguyen, M.; Zerbib, D.; Bernadou, J.; Daffe, M.; Labesse, G.; Quemard, A. Antimicrob. Agents Chemother. 2004, 48, 242-249.

(4) CCP4 Acta Crystallogr. 1994, D50, 760-763.

(5) Emsley, P.; Cowtan, K. Acta Crystallogr. 2004, D60, 2126-2132.

(6) Murshudov, G. N.; Vagin, A. A.; Dodson, E. J. Acta Crystallogr. 1997, D53, 240-255.

(7) Schuttelkopf, A. W.; van Aalten, D. M. Acta Crystallogr. 2004, D60, 1355-1363. 